\title{
Globally distributed Xyleborus species reveal recurrent intercontinental dispersal in a landscape of ancient worldwide distributions
}

\author{
Jostein Gohli ${ }^{1 *}$ (D) Tina Selvarajah², Lawrence R. Kirkendall ${ }^{2}$ and Bjarte H. Jordal ${ }^{1}$
}

\begin{abstract}
Background: Invasive species can have devastating effects on native ecosystems and therefore impose a significant threat to human welfare. The introduction rate of invasive species has accelerated dramatically in recent times due to human activity (anthropogenic effects), with a steadily growing pool of widespread tramp species. We present an in-depth analysis of four pantropical species of Xyleborus ambrosia beetles (Xyleborus volvulus, Xyleborus perforans, Xyleborus ferrugineus, and Xyleborus affinis) with similar ecology (fungus cultivation in dead wood), reproductive biology (permanent inbreeding) and genetic system (haplodiploidy). The unique combination of reproductive traits and broad host plant usage pre-adapts these beetles for colonizing of new areas.
\end{abstract}

Results: We found that all four species were broadly distributed long before human-assisted dispersal became common, and that the impact of anthropogenic effects varied among the species. For $X$. volvulus, X. perforans, and $X$. affinis there was evidence of ancient establishment in numerous regions, but also of abundant recent introductions into previously colonized areas. For $X$. ferrugineus, we found clear biogeographical structuring of old clades, but little evidence for recent successful introductions.

Conclusions: Our results indicate that current human-aided transoceanic dispersal has strongly affected the genetic makeup of three of the species in this study. However, current biogeographical patterns of all four species are equally, if not more strongly, influenced by ancient establishment on different continents.

Keywords: Ancestral reconstruction, Anthropogenic effects, Bark and ambrosia beetles, Biological invasions, Dispersal, Xyleborus

\section{Background}

Invasive species constitute a major threat to native ecosystems worldwide $[1,2]$. Many different types of organisms can be successful colonizers, and particularly those easily transported by humans over long distances [3]. Anthropogenic dispersal is therefore regarded as the most significant factor in explaining threats to ecosystems [2, 4] and agricultural crops [5]. However, longrange dispersal is not always human-aided and the

\footnotetext{
* Correspondence: Jostein.Gohli@gmail.com

'Natural History Collections, University Museum of Bergen, University of Bergen, P.O. box 78005020 Bergen, Norway

Full list of author information is available at the end of the article
}

relative importance of natural vs human-aided dispersal is often not obvious.

Even though many species are introduced to new continents or oceans every year, only a few become permanently established [6]. Serendipity plays a role in propagule establishment, but flexible habitat preferences and high propagule pressure are certainly important $[7,8]$. Certain organisms have biological traits that likely facilitate establishment after dispersal [pre-adapted colonizers; 6, 9, 10]. Among invasive insects, mites, annelids, and plants, species that reproduce by sibling mating (or selfing) or by clonal reproduction through parthenogenesis are overrepresented [11-14]. For instance, the bark and ambrosia beetle fauna (Scolytinae) on remote oceanic islands is 
generally represented by two or three times more sibmating species compared to the mainland [11], and nearly three-quarters of the established alien Scolytinae in North America are brother-sister maters [15].

With both inbreeding and parthenogenesis, a single mated female is sufficient for a species to become established in a new area $[10,16,17]$. Reproductive assurance is advantageous to insects such as bark beetles that depend on locating scattered, ephemeral resources, and enables long-distance colonization and establishment. For normally outbreeding species, a large number of introduced individuals [18] or repeated introductions [19] can ameliorate the effects of inbreeding depression. Permanent inbreeders [20], on the other hand, are expected to have purged strongly deleterious alleles early in a lineage's history, and both parthenogens and inbreeders have been under strong selection for combinations of genes which work well together. Regularly inbreeding species are thus expected to be largely immune to the effects of inbreeding that result from bottleneck events such as colonisations [21], and are therefore relatively unaffected by many ecological and genetic mechanisms normally causing Allee effects [22].

In both the North American and European wood boring fauna, exotic species are disproportionately ambrosia beetles that cultivate and feed upon mutualistic fungi in tunnels they excavate in dead trees $[15,23]$. The fungal symbionts are host generalists, which enable the beetles to breed in many host plants families [24, 25], pre-adapting them for successful colonization of distant regions $[4,10-13]$. Further, in contrast to the native faunas, exotic ambrosia beetles are almost all inbreeders [26, 27].

The ambrosia beetle genus Xyleborus contains many abundant and widespread invasive species [28-32]. All inbreed by sibling mating and all are haplodiploid (males are haploid and produced by unfertilized eggs). By mating with siblings,having the potential for re-mating with clonally produced sons in the absence of mates, and the ability to grow fungi for food in almost any kind of wood, Xyleborus and similar ambrosia beetles are exceptionally efficient at colonizing and establishing in new areas.

Human activity results in a constant stream of introductions of bark and ambrosia beetles to new areas [26, 3336]. For wood boring beetles such as these, the most common mechanism for intercontinental dispersal is transport in timber and wooden packing materials [26, 34]. They survive such transport particularly well, being ensconced in material which provides food, a buffered microenvironment, and protection from most natural enemies. Hence, a wide variety of exotic bark and ambrosia beetle species are regularly trapped near harbours around the world [26, 27, 34, 37-39]. While anthropogenic effects strongly influence the recent spread of these beetles, many species of
Xyleborus are also known from the earliest examinations of tropical scolytine fauna on different continents [40-42]. Their presence over several centuries may well be due to anthropogenic factors, but could also indicate prehistorical dispersal. It is therefore uncertain if human transport alone can explain the pantropical distribution of these beetles.

In order to test the relative importance of ancient vs. modern dispersal for current geographical distributions, we reconstructed the biogeographical history of four Xyleborus species. The species were chosen because they are largely pantropical in distribution and are among the most numerous ambrosia beetles wherever they are found [30, 43-45]. Due to their nearly global distribution, it has not been possible to determine their geographical origin. We envision three alternative scenarios for the biogeographical history of these species: (i) If Xyleborus beetles became widely established before the dawn of human influence on species distributions, we expect evidence for ancient establishment in multiple areas. Ancient distributions would be reflected in multiple divergent clades that are largely restricted to specific regions. High haplotypic diversity within several geographical regions would furthermore imply stable populations since prehistorical time. (ii) Contrarily, if a current pantropical distribution is due largely to multiple human-aided dispersal events, we expect the source area to be represented by a single genetically diverse clade. Very recent colonisations of new regions would then be evident from young derived clades nested within the aforementioned clade. (iii) A third possible result is a combination of the features from (i) to (ii), which would result from ancient dispersal to multiple regions followed by recent human-aided introductions to the same and other areas.

\section{Methods}

Females of the four focal species were sampled from four continents to 20 countries (Additional file 1: Table S1). Beetles were collected by hand, or in ethanol-baited flight intercept traps, or light traps, and preserved in $95 \%$ ethanol. All specimens were identified based on morphology (BHJ and LRK) before extraction. We extracted DNA from 53 Xyleborus ferrugineus, $62 X$. affinis, 25 X. volvulus, and 30 X. perforans individuals. We included sequences from Coccotrypes cyperi, C. advena, Ozopemon brownei, and Xylosandrus morigerus as outgroups [46], and we included data from nine related Xyleborus species to test for monophyly in our focal species (Genbank acc. no and metadata in Additional file 1: Table S3).

We sequenced one mitochondrial gene, cytochrome oxidase I (COI), and one nuclear gene, Elongation Factor 1-alpha $(E F 1 \alpha)$. The rapidly evolving mitochondrial gene 
is suited for examining population structure, while the nuclear gene may be more informative when attempting to resolve older relationships among species. A subset of individuals representing all identified COI haplo-groups was selected for EF1 $\alpha$ sequencing (Additional file 1: Table S1). Before combining the two loci in an analytical framework, we assessed their phylogenetic concordance with a Congruence Among Distance Matrices (CADM) test [47]. Using the function tanglegram from the R package dendextend, we visualized separate phylogenetic reconstructions for each locus-and their concordance-as a tanglegram.

We extracted genomic DNA using E.Z.N.A ${ }^{\circ}$ Tissue DNA Kit (Omega Bio-Tek, Atlanta, GA, USA) following the manufacturer's protocol. 610 base pairs (bp) of COI gene and $1043 \mathrm{bp}$ of the EF1 $\alpha$ nuclear gene were amplified and sequenced using primers from Normark et al. [48; Additional file 1: Table S2]. PCR reactions were performed in $25 \mu \mathrm{L}$ volume with $10 \mu \mathrm{M}$ of each forward and reverse primer, $0.25 \mathrm{mM}$ dNTPS, $0.625 \mathrm{U}$ HotStar Taq DNA Polymerase, 17.4 $\mu \mathrm{L} \mathrm{ddH}_{2}, 0,2.5 \mu \mathrm{L}$ of $10 \mathrm{x}$ PCR buffer, $25 \mathrm{mM} \mathrm{MgCl} 2$ and $1.0 \mu \mathrm{L}$ of DNA template using the following PCR cycle: 95 , $15 \mathrm{~min} ; 35$ cycles $\left[94^{\circ}, 30 \mathrm{~s} ; 48^{\circ}, 45 \mathrm{~s} ; 72^{\circ}, 60 \mathrm{~s}\right] ; 72^{\circ}, 7 \mathrm{~min}$. PCR reactions for $\mathrm{EF} 1 \alpha$ were performed in $26 \mu \mathrm{L}$ volume containing similar ingredients and concentrations as for $\mathrm{CO} 1$ gene amplifications, but with $2.0 \mu \mathrm{L}$ of DNA. A touchdown PCR profile was employed for this nuclear gene: $95^{\circ}$, 15 min; 13 cycles TD $\left[94^{\circ}, 30 \mathrm{~s} ; 58-44^{\circ}, 45 \mathrm{~s} ; 72^{\circ}, 30 \mathrm{~s}\right]$; 26 cycles $\left[94^{\circ}, 30 \mathrm{~s} ; 44^{\circ}, 45 \mathrm{~s} ; 72^{\circ}, 30 \mathrm{~s}\right] ; 72^{\circ}, 6 \mathrm{~min}$. We purified amplified DNA using ExoSAP (Exonuclease I-Shrimp Alkaline Phosphatase) and sequenced in both directions using standard protocol for ABI BigDye ${ }^{\circ}$ Terminator v3.1 Cycle sequencing kit (Applied Biosystems).

Sequence contigs were assembled and edited using SEQMAN II, a contig assembly module from DNASTAR Lasergene $6^{\circ}$, and aligned using ClustalW [49] in BioEdit 7.0.1 [50]. The alignments were further refined using amino acid translation. We found no indications of nuclear insertions (NUMTs) of the COI gene in our sequenced data (all single-peak chromatograms, no stop codons or indels). COI (acc.no: KP941137-KP941327) and EF1 $\alpha$ (acc.no: KP941328-KP941418) sequences are deposited in Genbank.

The phylogenetic and biogeographical reconstruction included both genes and all sequence data (194 individuals: the four focal species, outgroup, and ingroup), and seven geographical regions (Afrotropical mainland, Afrotropical islands (Indian Ocean), Neotropical mainland, Neotropical islands (Pacific Ocean), Indo-Malaysia, Australasia, Australasian small islands (Pacific Ocean). Haplotype networks were constructed independently for both COI and EF1 $\alpha$ for this dataset using haploNet from the pegas $\mathrm{R}$ package [51]. 2) Ancestral reconstruction of geographical distribution was done by defining geographical location as discrete traits in BEAST, using a symmetric trait substitution model. Social network was inferred with BSSVS [52] in BEAST. The biogeographical reconstruction was performed using a conditional reference prior [53]. Since we were interested in identifying supported diffusions (dispersal/migration routes) for each species, we performed analyses on each individual species set using the same approach as outlined above. The results from these latter analyses were further analysed in SPREAD [54] (a tool developed for epidemiology studies, which can also be used to visualize biogeographical histories in general, e.g. $[55,56])$. A Bayes factor cutoff of 10 was implemented so that only highly supported diffusions were returned by the software.

The best-fit evolutionary models of sequence evolution were determined with jModeltest 2.1.3 [57, 58] (Additional file 1: Table S4 and Additional file 1: Table S5), and phylogenetic and biogeographical reconstructions were performed with BEAST v1.8.2 [59]. The Yule speciation process tree prior was used in the reconstruction which included all species and the constant size coalescence tree prior was used for reconstructions of individual species datasets. The larger dataset was run for $70 \mathrm{M}$ and the smaller datasets for $20 \mathrm{M}$ generations. Mean values and effective sample size (ESS values) for all parameters were obtained using Tracer [60] with $10 \%$ burn-in (Additional file 1: Table S4 and Additional file 1: Table S5). Maximum clade credibility trees were obtained using TreeAnnotator from the BEAST package.

In addition to phylogenetic and biogeographic analyses, we performed a molecular dating analysis using $\mathrm{COI}$ and $\mathrm{EF} 1 \alpha$ data. For time calibration, we referred to an unpublished phylogenetic analysis of Scolytinae (317 spp.) which include four fossil calibration points. The sister group of Xyleborus in this large analysis was used as the outgroup in the calibration analysis (Additional file 1: Table S3). In the original higher level analysis, Xyleborus was represented by $X$. alluaudi and $X$. affinis. We thus included $X$. alluadi in order to evaluate the age estimates for the MRCA for these two species in both analyses (as a qualitative test). The stem age of Xyleborus was set to $17.3 \mathrm{Ma}$ based on our global Scolytinae dating, with a normal distribution prior ( $(\mathrm{tddev}=0.173 \mathrm{myr}$ ). Since our system is relatively young and contain similar species, we opted for a strict clock rate prior with rate estimation for both markers and a Yule speciation prior in BEAST.

Tests of molecular variance (AMOVA) were performed in Arlequin v3.5 [61]. We performed two AMOVA tests based on different sets of geographical regions. In the first test, we clustered populations into the same seven regions as used in the large phylogenetic reconstruction (Afrotropical mainland, Afrotropical islands (Indian 


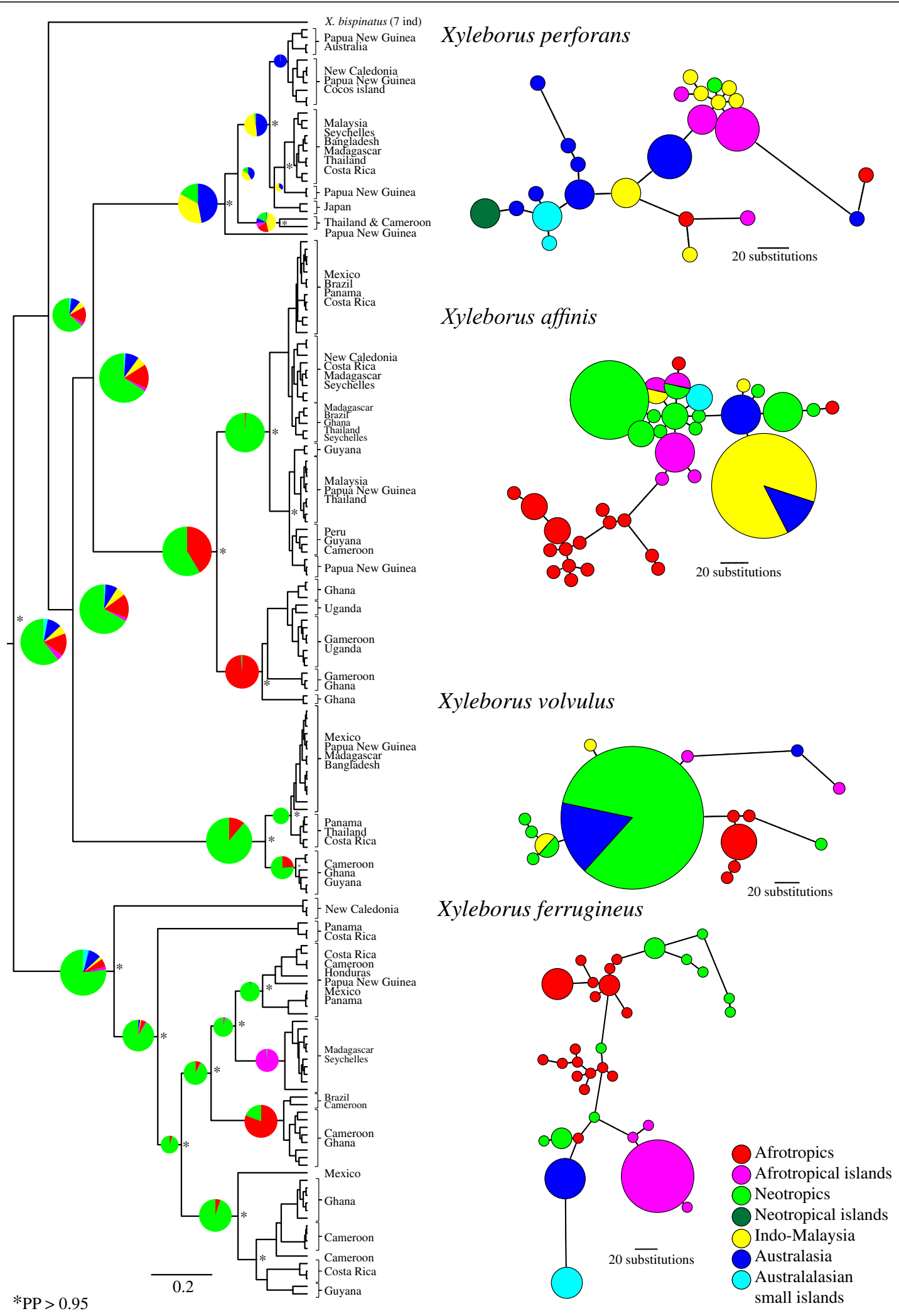

Fig. 1 (See legend on next page.) 
(See figure on previous page.)

Fig. 1 Biogeographical and phylogenetic reconstruction, and haplotype network. Legend: A phylogenetic tree for the four monophyletic focal species and one ingroup species (X. bispinatus) constructed using COI and EF1a. The phylogeny was constructed with sequences from 12 species as outgroup (Additional file 1: Table S3), which were removed from this figure. Posterior probability values are indicated by asterisks on nodes (*PP >0.95); numerous less important, yet strongly supported nodes (i.e., nodes nested deep within clades; PP >0.95), are not presented. Scale bars indicate branch length, which correspond to number of substitutions. Pie charts on branches show the relative probabilities of different geographical regions from the ancestral reconstruction. Circle sizes on trees contain no information, whereas circle sizes in the haplotype networks indicate number of individuals per haplotype. The haplotype networks shown here are based on COI only. Colour codes indicate regions, as shown in the bottom right corner, and are the same for pie charts in branches and in networks. Scale bars in the haplotype networks show the relationship between number of substitutions and branch lengths (these differ slightly among the haplotype networks)

Ocean), Neotropical mainland, Neotropical islands (Pacific Ocean), Indo-Malaysia, Australasia, Australasian small islands (Pacific Ocean)); in the second test, we merged the oceanic regions with their continental counterparts giving a total of four regions. COI and EF1 $\alpha$ were analysed separately. We also estimated genetic diversity in terms of segregating sites, nucleotide and haplotype diversity $(S, \pi$ and $H)$ along with Tajima's $D$, which tests for neutrality and recent population expansion or contraction, using DNAsp [62]. The association between genetic and geographical distance was evaluated with mantel tests performed in $R$ using mantel.rtest [63]. To evaluate the distribution of genetic distances among haplotypes within species, mismatch distribution plots for COI were created in $R$ [64] using the function MMD from the pegas package [51].

\section{Results}

A CADM global test of COI and EF1 $\alpha$ was significant (Friedman's $X^{2}=3518.3$; Kendall's $W=0.820, P=0.0001$ ), implying that the two molecular markers are congruent [47] and thus suitable for concatenation in an analytical framework. COI and EF1 $\alpha$ phylogenies and their concordance are shown in a tanglegram (Additional file 1: Figure S2). Phylogenetic reconstructions indicated that all four focal species constitute monophyletic groups (Fig. 1).

Each species contained distinct intraspecific clades separated by a large number of substitutions, especially in the COI data (Fig. 1). Considerable geographical mixing was observed within subclades in three of the four species ( $X$. perforans, $X$ affinis and $X$. volvulus) except for one $X$. affinis clade that was purely Afrotropical. Xyleborus ferrugineus differed from the other species, containing numerous old clades that were generally restricted to distinct geographical regions. The differences noted between X. ferrugineus and the other three species were also apparent in the COI mismatch distribution plots (Additional file 1: Figure S3) showing large genetic distances between haplotypes in $X$. ferrugineus, while shorter genetic distances predominate in the mismatch distributions for the other three species.

The biogeographical reconstruction revealed that $X$. ferrugineus and $X$. volvulus most likely originated in the Neotropics (pie charts on phylogeny in Fig. 1). Neotropical and Afrotropical origin were both highly likely for $X$. affinis. For X. perforans, an Australasian origin had the highest probability, but Neotropical and Indo-Malaysian origins also had substantial probability scores.

COI haplotype networks were largely congruent with the phylogenies (Fig. 1). We found large genetic distances among clusters in all four species, indicating ancient splits between intra-specific lineages. Haplotype clusters were not geographically homogeneous for $X$. affinis, $X$. volvulus and $X$. perforans; clusters contained individuals predominantly from one geographical region together with one or a few individuals from a separate region. A few single haplotypes were shared by individuals from different geographical regions. Sequences of $X$. ferrugineus showed stronger geographical structuring, with geographically homogeneous haplotype clusters. We observed only one example of a very recent dispersal event (between the Neotropics and Afrotropics) in this species. There was also a tendency towards higher haplotypic diversity within geographical regions in X. ferrugineus, in particular the Afrotropical and Neotropical regions. The EF1 $\alpha$ haplotype networks revealed little additional information to those of COI, but rather supported the general patterns seen in Fig. 1 (Additional file 1: Figure S4). As expected, there was significantly less fine scale resolution in the EF1 $\alpha$ haplotype network compared to the COI network, which is due to the lower level of genetic variation in EF1 $\alpha$ (Table 2).

The molecular dating analysis (Fig. 2) indicated a Xyleborus crown age of $11.8 \mathrm{Ma}$, with a $95 \%$ highest posterior density (HPD) interval of [10.1-13.7 Ma]. The estimated minimum (crown) ages of our focal species were as follows: X. perforans-3.3 Ma; 95 \% HPD [2.5-4.1 Ma], X. affinis-3.7 Ma; 95 \% HPD [2.8-4.6 Ma], X. volvulus-1.6 Ma; 95 \% HPD [1.1-2.2 Ma], and X. ferrugineus-8.5 Ma; $95 \%$ HPD [6.9-10.4 Ma]. The estimated age of the $X$. alluaudiaffinis MRCA in our analysis (9.5 Ma), was quite close to the estimated age of the same node $(10.8 \mathrm{Ma})$ in the larger analysis, from where we obtained our stem calibration age for Xyleborus.

In tests of molecular variance (AMOVA; Table 1), partitioning of variance varied significantly based on number of regions included (four vs. seven, treating oceanic islands as separate from continents). For all four species, there was a much larger proportion of variance among 


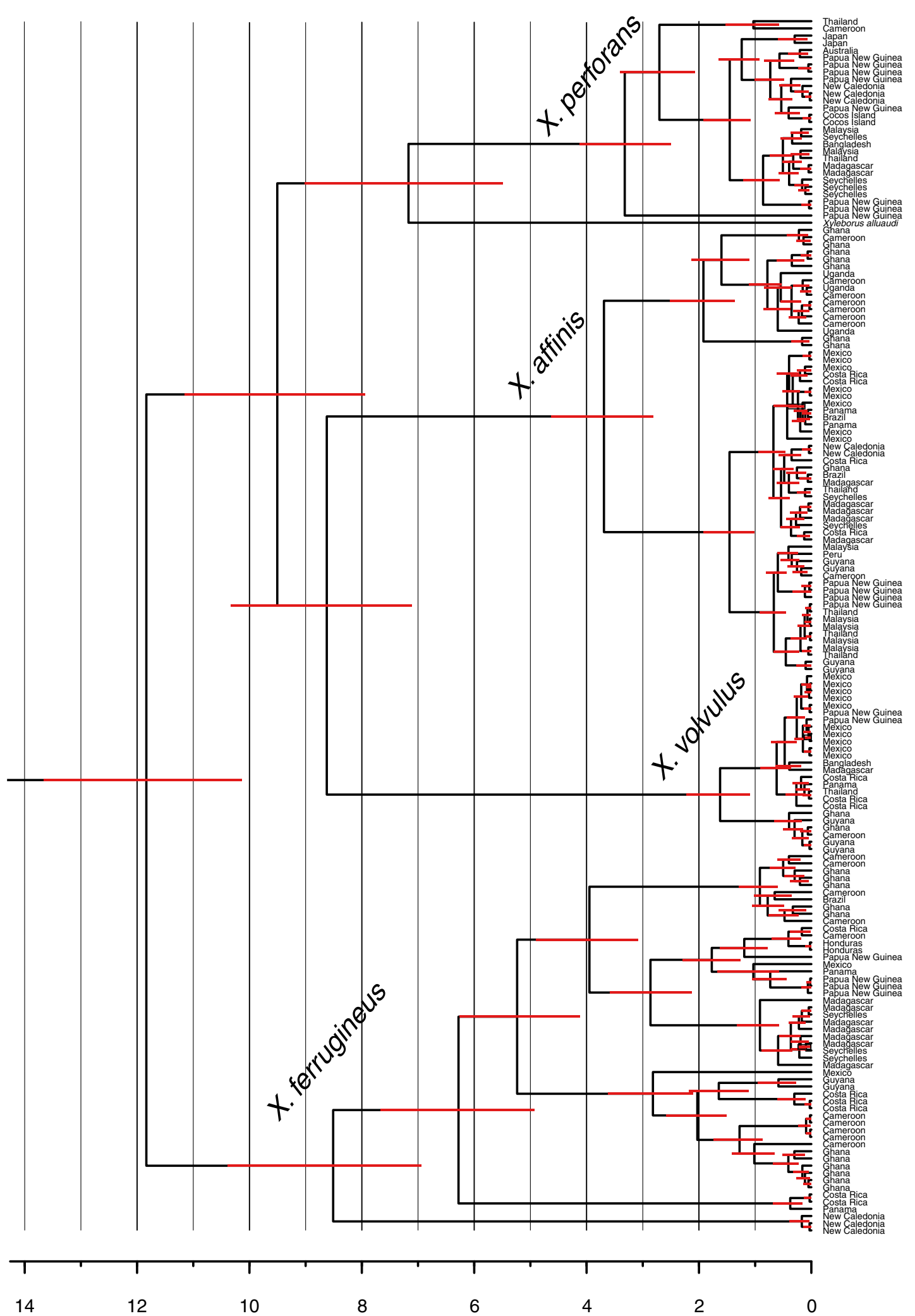

Fig. 2 Dating analysis. Legend: Time calibrated analysis of five species of Xyleborus (Xyleborus stem=17.3 Ma). The scale axis is in million years. $95 \%$ node height highest posterior density intervals are plotted on each node. Outgroup taxa are not shown (see methods) 
Table 1 Tests of molecular variance (AMOVA) for the four species and both genetic markers. The seven regions are Afrotropics, Afrotropical islands (Indian Ocean), Neotropics, Neotropical islands (Pacific Ocean), Indo-Malaysia, Australasia, Australasia small islands (Pacific Ocean). In the four regions the oceanic regions were merged with their continental counterparts

\begin{tabular}{|c|c|c|c|c|c|c|c|c|c|c|c|c|c|}
\hline & \multirow[b]{2}{*}{ Source of variation } & \multicolumn{5}{|c|}{ Seven regions } & & \multicolumn{5}{|c|}{ Four regions } & \\
\hline & & df & $\begin{array}{l}\text { Sum of } \\
\text { squares }\end{array}$ & $\begin{array}{c}\text { Variance } \\
\text { components }\end{array}$ & $\begin{array}{c}\% \\
\text { variation } \\
\end{array}$ & $\begin{array}{l}\text { Fixation } \\
\text { indices }\end{array}$ & & df & $\begin{array}{l}\text { Sum of } \\
\text { squares }\end{array}$ & $\begin{array}{l}\text { Variance } \\
\text { components }\end{array}$ & $\begin{array}{c}\% \\
\text { variation } \\
\end{array}$ & $\begin{array}{l}\text { Fixation } \\
\text { indices }\end{array}$ & \\
\hline \multicolumn{14}{|c|}{ X. affinis: } \\
\hline & Among regions & 5 & 446.7 & 8.5 & 59.6 & $\Phi_{C T}: 0.59$ & $* *$ & 3 & 280.3 & 4.7 & 34.0 & $\Phi_{C T}: 0.34$ & * \\
\hline \multirow[t]{3}{*}{$\mathrm{COI}$} & $\begin{array}{l}\text { Among populations within } \\
\text { regions }\end{array}$ & 9 & 92.9 & 1.6 & 11.5 & $\Phi_{S C}: 0.28$ & $* * *$ & 11 & 259.3 & 5.1 & 36.5 & $\Phi_{S C}: 0.55$ & $* *$ \\
\hline & Within populations & 46 & 189.9 & 4.1 & 29.0 & $\Phi_{\mathrm{ST}}: 0.71$ & $* * *$ & 46 & 189.9 & 4,1 & 29.5 & $\Phi_{\mathrm{ST}}: 0.71$ & $* *$ \\
\hline & Among regions & 5 & 12.5 & 0.5 & 59.4 & $\Phi_{C T}: 0.59$ & * & 3 & 6.8 & 0.1 & 17.5 & $\Phi_{\mathrm{CT}}: 0.18$ & $* * *$ \\
\hline \multirow[t]{2}{*}{ EF1a } & $\begin{array}{l}\text { Among populations within } \\
\text { regions }\end{array}$ & 5 & 2.5 & 0.1 & 14.0 & $\Phi_{S C}: 0.34$ & * & 7 & 8.2 & 0.4 & 54.1 & $\Phi_{S C}: 0.66$ & $* *$ \\
\hline & Within populations & 19 & 4.0 & 0.2 & 26.6 & $\Phi_{\mathrm{ST}}: 0.73$ & $* * *$ & 19 & 4.0 & 0.2 & 28.5 & $\Phi_{S T}: 0.71$ & * \\
\hline \multicolumn{14}{|c|}{ X. ferrugineus: } \\
\hline & Among regions & 4 & 513.6 & 11.8 & 45.8 & $\Phi_{C \top}: 0.45$ & $* * *$ & 2 & 178.2 & 2.5 & 10.0 & $\Phi_{C T}: 0.10$ & \\
\hline \multirow[t]{3}{*}{$\mathrm{COI}$} & $\begin{array}{l}\text { Among populations within } \\
\text { regions }\end{array}$ & 7 & 138.3 & 2.4 & 9.1 & $\Phi_{S C}: 0.17$ & & 9 & 473.7 & 10.6 & 42.9 & $\Phi_{S C}: 0.48$ & $* * *$ \\
\hline & Within populations & 38 & 442.1 & 11.6 & 45.1 & $\Phi_{\mathrm{ST}}: 0.55$ & $* * *$ & 38 & 442.1 & 11.6 & 47.2 & $\Phi_{\text {ST }}: 0.53$ & *** \\
\hline & Among regions & 5 & 20.7 & -1.0 & -33.3 & $\Phi_{C T}:-0.33$ & & 3 & 15.1 & 0.0 & -1.5 & $\Phi_{C T}:-0.01$ & \\
\hline \multirow[t]{2}{*}{ EF1a } & $\begin{array}{l}\text { Among populations within } \\
\text { regions }\end{array}$ & 3 & 12.2 & 2.2 & 77.0 & $\Phi_{S C}: 0.58$ & & 5 & 17.7 & 1.3 & 45.8 & $\Phi_{S C}: 0.45$ & \\
\hline & Within populations & 10 & 16.1 & 1.6 & 56.2 & $\Phi_{\mathrm{ST}}: 0.44$ & * & 10 & 16.1 & 1.6 & 55.7 & $\Phi_{\text {ST }}: 0.44$ & \\
\hline \multicolumn{14}{|c|}{ X. perforans: } \\
\hline & Among regions & 6 & 182.5 & 1.3 & 9.3 & $\Phi_{C T}: 0.09$ & & 3 & 88.6 & -0.2 & -1.5 & $\Phi_{C T}:-0.01$ & \\
\hline \multirow[t]{3}{*}{$\mathrm{COI}$} & $\begin{array}{l}\text { Among populations within } \\
\text { regions }\end{array}$ & 7 & 128.5 & 6.3 & 44.3 & $\Phi_{S C}: 0.49$ & & 10 & 222.4 & 7.7 & 54.6 & $\Phi_{S C}: 0.54$ & $* * *$ \\
\hline & Within populations & 20 & 132.6 & 6.6 & 46.4 & $\Phi_{\mathrm{ST}}: 0.54$ & $* * *$ & 20 & 132.6 & 6.6 & 46.9 & $\Phi_{\mathrm{ST}}: 0.53$ & *** \\
\hline & Among regions & 5 & 6.4 & -1.5 & -98.0 & $\Phi_{C T}:-0.98$ & & 3 & 4.1 & -0.2 & -12.9 & $\Phi_{C T}:-0.12$ & \\
\hline \multirow[t]{2}{*}{ EF1a } & $\begin{array}{l}\text { Among populations within } \\
\text { regions }\end{array}$ & 1 & 3.0 & 1.5 & 99.0 & $\Phi_{S C}: 0.50$ & & 3 & 5.3 & 0.2 & 14.9 & $\Phi_{S C}: 0.13$ & \\
\hline & Within populations & 2 & 3.0 & 1.5 & 99.0 & $\Phi_{\text {ST }}: 0.01$ & & 2 & 3.0 & 1.5 & 98.1 & $\Phi_{\text {ST }}: 0.02$ & \\
\hline \multicolumn{14}{|c|}{ X. volvulus: } \\
\hline & Among regions & 4 & 100.1 & 2.6 & 20.5 & $\Phi_{C T}: 0.21$ & & 3 & 58.7 & 0.1 & 0.4 & $\Phi_{C T}: 0.01$ & $* *$ \\
\hline \multirow[t]{3}{*}{$\mathrm{COI}$} & $\begin{array}{l}\text { Among populations within } \\
\text { regions }\end{array}$ & 5 & 71.8 & 2.5 & 19.2 & $\Phi_{S C}: 0.24$ & $* *$ & 6 & 113.3 & 4.3 & 35.5 & $\Phi_{S C}: 0.36$ & \\
\hline & Within populations & 19 & 146.6 & 7.7 & 60.2 & $\Phi_{\text {ST }}: 0.40$ & * & 19 & 146.6 & 7.7 & 64.1 & $\Phi_{\text {ST }}: 0.36$ & * \\
\hline & Among regions & & & & & & & 3 & 2.9 & 0.1 & 24.3 & $\Phi_{\mathrm{CT}}: 0.24$ & \\
\hline \multirow[t]{2}{*}{ EF1a } & $\begin{array}{l}\text { Among populations within } \\
\text { regions }\end{array}$ & & & - & & & & 2 & 2.0 & 0.4 & 59.7 & $\Phi_{S C}: 0.79$ & * \\
\hline & Within populations & & & & & & & 7 & 0.7 & 0.1 & 16.1 & $\Phi_{\text {ST }}: 0.84$ & $* * *$ \\
\hline
\end{tabular}

Fixation indices: among regions, $\varphi_{\mathrm{CT}} ;$ among populations within regions, $\varphi_{\mathrm{S}} ;$ within populations, $\varphi_{\mathrm{ST}}$

$P$-values for $\%$ variation and corresponding fixation indices: ${ }^{*} P<0.05,{ }^{*} P<0.01,{ }^{* *} P<0.001$

The test for seven regions for $X$. volvulus and EF1a was not possible since the oceanic regions were not represented in the data

regions if oceanic regions were included compared to that observed when defining only four main regions for the analysis.

Xyleborus ferrugineus was more genetically diverse, at both loci, than the other three species (Table 2). Tajima's $D$ was significant only for EF1 $\alpha$ data, in $X$. perforans and
$X$. affinis. Tajima's $D$ values for the two species $(-1.901$ and-1.848, respectively) indicate lower than expected genetic diversity. Mantel tests of COI genetic and geographic distance were significant and positive for three of the species $(P<0.05 ; X$. volvulus: $P=0.077$; Additional file 1: Figure S5); the strongest associations were 
Table 2 Three measures of genetic diversity and Tajima's D for the four focal species

\begin{tabular}{|c|c|c|c|c|c|c|c|c|c|c|}
\hline & loci & $\mathrm{n}$ & $\begin{array}{l}\text { Number of } \\
\text { segregating } \\
\text { sites }(S)\end{array}$ & $\begin{array}{l}\text { Total number } \\
\text { of mutations }\end{array}$ & $\begin{array}{l}\text { Nucleotide } \\
\text { diversity }(\pi)\end{array}$ & $\begin{array}{c}\text { Standard } \\
\text { deviation of } \pi\end{array}$ & $\begin{array}{l}\text { Total number } \\
\text { of haplotypes }\end{array}$ & $\begin{array}{l}\text { Haplotype } \\
\text { diversity(Hd) }\end{array}$ & $\begin{array}{c}\text { Standard } \\
\text { deviation of } \mathrm{Hd}\end{array}$ & Tajima's D \\
\hline X. volvulus & $\mathrm{COI}$ & 29 & 122 & 150 & 0.0457 & 0.0130 & 15 & 0.828 & 0.005 & $-1.573^{P>0.10}$ \\
\hline$X$. perforans & $\mathrm{COl}$ & 34 & 119 & 156 & 0.0517 & 0.0097 & 24 & 0.979 & 0.012 & $-1.276^{\rho>0.10}$ \\
\hline$X$. affinis & $\mathrm{COl}$ & 61 & 73 & 81 & 0.0424 & 0.0034 & 33 & 0.948 & 0.017 & $0.572^{P>0.10}$ \\
\hline$X$. ferrugineus & $\mathrm{COl}$ & 50 & 134 & 169 & 0.0935 & 0.0040 & 33 & 0.968 & 0.000 & $0.502^{P>0.10}$ \\
\hline X. volvulus & EF1a & 13 & 3 & 3 & 0.00125 & 0.0004 & 3 & 0.500 & 0.136 & $-0.143^{\rho>0.10}$ \\
\hline X. perforans & EF1a & 9 & 14 & 14 & 0.00492 & 0.0021 & 4 & 0.583 & 0.034 & $-1.901^{P<0.05}$ \\
\hline$X$. affinis & EF1a & 30 & 12 & 12 & 0.00141 & 0.0004 & 8 & 0.694 & 0.059 & $-1.848^{p<0.05}$ \\
\hline X. ferrugineus & EF1a & 19 & 25 & 26 & 0.00634 & 0.0017 & 12 & 0.918 & 0.047 & $-1.056^{P>0.10}$ \\
\hline
\end{tabular}

identified in $X$. perforans (obs $=0.326, P=0.011$ ) and $X$. ferrugineus (obs=0.47, $P<0.001$ ). A Mantel test of $\mathrm{EF} 1 \alpha$ genetic distance and geographic distance was significant and positive for $X$. affinis (obs=0.221, $P=0.012$ ) and $X$. ferrugineus (obs $=0.412, \quad P=0.021$; Additional file 1 : Figure S5). The same tests for EF1 $\alpha$ were not significant for $X$. volvulus and $X$. perforans, which may be due to insufficient data.

\section{Discussion}

For all four Xyleborus species, we found conclusive evidence for colonization of separate continents millions of years ago (see Fig. 2). With the exception of X. ferrugineus, these species also show evidence of accelerated rates of colonization in recent times (Figs. 1 and 2), which likely stems from increased introductions through anthropogenic effects. However, the geographically broad distribution of these species, which was discovered during the earliest insect inventories in tropical Africa, South America and SE-Asia [40-42], is not primarily a result of introductions just prior to these first inventories. The results from our dating analysis and biogeographically structured COI haplotype clusters clearly indicate ancient dispersal and demonstrates that anthropogenic effects are not a necessity for the global spread of these or similar species.

The emerging picture of a clade with many widespread species dispersing since the time of their origin is a relatively novel finding and distinguishes this group from many other invasive organisms such as certain termites $[65]$ and ants $[66,67]$ and several other bark and ambrosia beetles. The coffee berry borer (Hypothenemus ham$p e i)$, for instance, has considerable genetic variation only in its native African region, with recent dispersal across continents following the cultivation of coffee [68]. Termites are particularly comparable in terms of ecology and includes the dry-wood inhabiting termites; despite dozens of widespread tramp species, none of these are ancient globetrotters, which is surprising given a flexible reproductive system and capacity for rafting in draft wood [65]. In this regard, termites show many similarities with a group of ambrosia beetles in the weevil subfamily Platypodinae, where a handful of recent world expansions is the exception among otherwise highly endemic beetles [69]. In this perspective it is truly remarkable that several species of Xyleborus have such a genuinely wide distribution pattern. However, they do possess a truly remarkable mode of reproduction that possibly holds the key for understanding their wide distribution. They are permanent inbreeders, hence inseminated before leaving their nest, and can even mate with sons produced from unfertilized haploid eggs [70]. Although there are many other species of Xyleborini that have very narrow distributions, species from this tribe are, together with another group of permanent inbreeders in the genus Hypothenemus, clearly overrepresented among the most widespread forest insects, indicative of their colonisation ability [70, 71].

Inferring the geographical origin of widespread Xyleborus is not straightforward given their complex patterns of repeated dispersal across and between continents. A close evolutionary relationship between a large clade of endemic Neotropical genera (Sampsonius, Dryocoetoides, Coptoborus and Theoborus) and the clade of widespread Xyleborus species may indicate that the Neotropical region is important in their evolutionary history [72]. However, some of the closest relatives of our focal species are endemic to the Afrotropical region (e.g. $X$. alluaudi and related species) [72], which complicates the inference of biogeographical history from such higher level taxonomy, and highlights that dispersal, not vicariance, is likely the primary driver of biogeographical structure in this group. Our biogeographical analyses support the Neotropical association in three of the focal species (ambiguous in $X$. perforans). It should be pointed out, however, that the reconstructed region for $X$. affinis seems to be strongly affected by the underlying node. Since the topology at this node has poor support (posterior probability $=0.87$ ), it may be unwise to emphasize this state when determining the ancestral region. This, 
together with the high haplotypic diversity in the Afrotropics, suggests an Afrotropical origin isfor $X$. affinis.

Differences in dispersal rates among the focal species were illustrated by the high number of unconnected locations for $X$. ferrugineus in the SPREAD analysis, as compared to $X$. affinis and $X$. perforans in particular (Fig. 3). This is unsurprising given the low occurrence of recent introductions to new regions for $X$. ferrugineus, as evident from the limited number of shared or similar haplotypes between regions (Fig. 1; haplotype network). High haplotypic diversity within multiple regions (Fig. 1) furthermore suggests enduring populations of this species, only seen elsewhere in the Afrotropical clade of X. affinis. This interpretation is supported by the distribution of node ages among the four species in the phylogeny: the nodes separating lineages in $X$. ferrugineus are substantially older than those observed in the other three species, as also reflected in the genetic distances between alleles in the COI mismatch distribution plots (Additional file 1: Figure S3). It should be mentioned that the EF1 $\alpha$ mismatch distributions were similar among all four species, which is likely due to EF1 $\alpha$ not having captured the most recent divergences. This difference in resolution between COI and $\mathrm{EF} 1 \alpha$ can be seen in their haplotype networks (Fig. 1, and

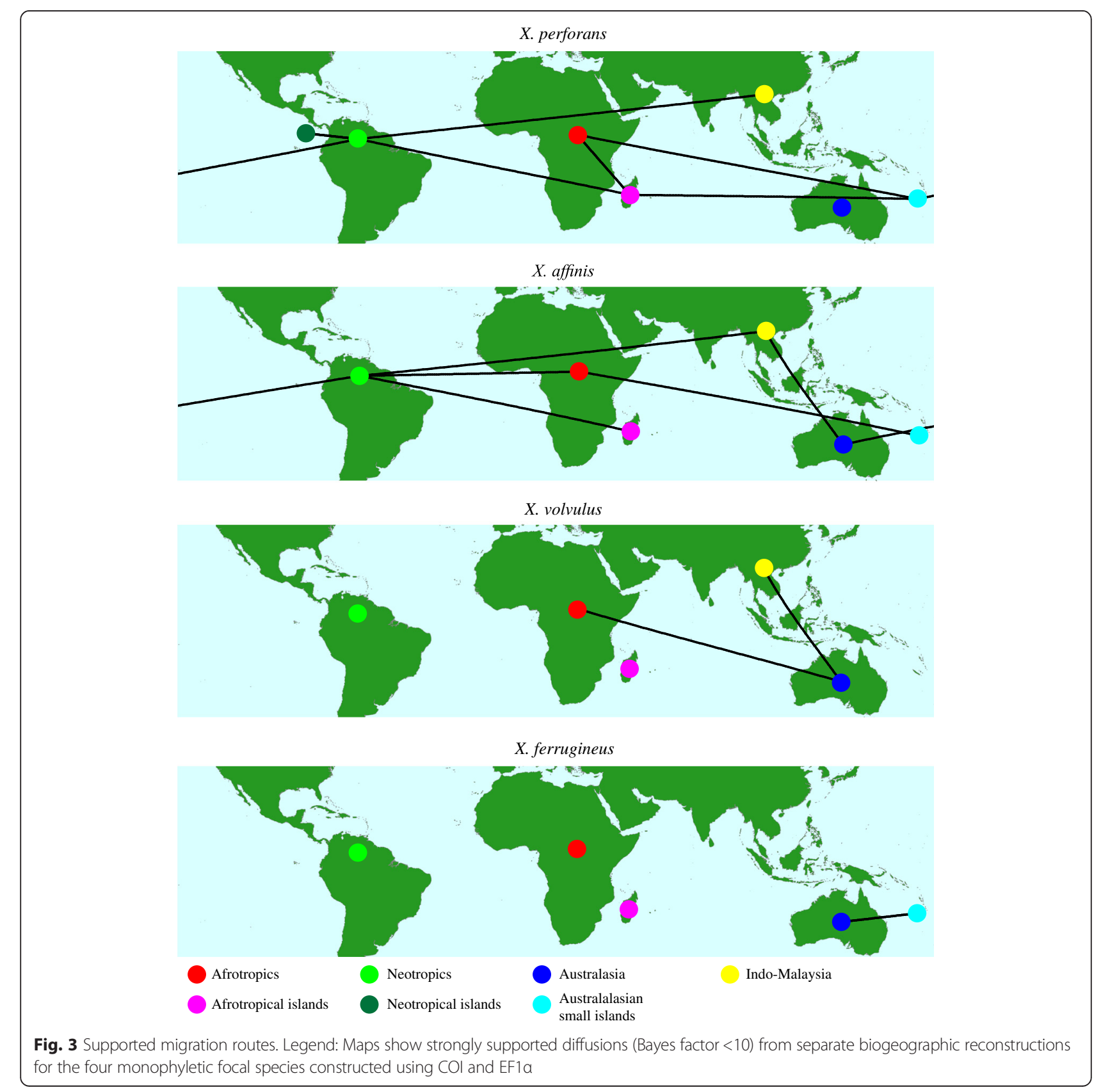


Additional file 1: Figure S4).Why does $X$. ferrugineus exhibit these largely unique characteristics? In particular, why have its ancient and geographically pure clades not been eroded by the recent spread and establishment seen in the other three species? Incomplete or biased sampling of individuals may limit the potential detection of more recently introduced lineages. However, that such lineages should be excluded by chance alone seems unlikely given the high representation of new introductions in the other species and the fact that $X$. ferrugineus has the second highest sample size (53 individuals). Some of these results (higher genetic diversity, deeper phylogenetic divergences) can be explained by $X$. ferrugineus simply being older than its three related species. Why this species seems largely unaffected by anthropogenic effects-in stark contrast to the other Xyleborus species-is a question that deserves further study at a finer scale.

Given that ancient long-range dispersal has occurred repeatedly in this clade of Xyleborus, it may not be unrealistic to expect cryptic speciation in the absence of sexual selection [70,73]. Several previous synonyms of $X$. ferrugineus has recently been resurrected to full species status [71, 74], which makes us alert to this possibility. We note that the New Caledonia population, which likely constitutes a very old dispersal event from the Neotropics, was separate from the other populations in both data sets (COI and EF1 $\alpha$; Additional file 1: Figure S2), but without any morphological differentiation. Xyleborus bispinatus and $X$. impressus, which were previously considered as $X$. ferrugineus, can on the other hand be readily distinguished genetically and morphologically and hence they are more clearly separated than the New Caledonia population. It is furthermore possible that broader geographical sampling of $X$. ferrugineus also will reduce some of the genetic gaps observed between populations of this species. Questions have been raised about the validity of species status of the near identical $X$. volvulus and $X$. perforans $[45,75]$. Our data nevertheless solved these issues confidently and we conclude that $X$. volvulus and $X$. perforans represent two individual species-both with regard to phylogenetic monophyly, and to their separate biogeographical origins. However, they are both globally widespread, and not restricted to the Neotropics and the Old World, respectively, as previously assumed [44].

\section{Conclusion}

We have tested the hypothesis that the global distributions in many Xyleborus species were fostered by human transportation. We found ample evidence for recent colonisations of new regions in three of the four examined Xyleborus species, which is in line with this hypothesis. However, the genetic data also strongly suggest that all four species were present across most of their current distributional range several million years ago, which was clearly before humans crossing the oceans. The combination of a pre-adapted biology for propagule establishment far from the source population, and the frequent transportation of wood material by humans in modern times, has radically increased migration rates in these beetles. It is therefore not surprising that many species of Xyleborus are among the most frequently collected species in any tropical or subtropical region.

\section{Availability of supporting data}

Supporting figures and tables are found in the additional file. All analysed DNA sequences are available in Genbank. COI acc.no: KP941137-KP941327), EF1 $\alpha$ acc.no: KP941328-KP941418, accession numbers for ingroup and outgroup sequences are listed in (Additional file 1: Table S3).

\section{Additional file}

Additional file 1: Supplemental tables and figures: Table S1.-Collected data and sequencing coverage for COI and EF1a. Table S2.--Sequencing primers. Table S3.-COut and ingroup specimen collection data, with Genbank accession numbers. Table S4.-Evolutionary models and rates, and summary statistics including ESS values from the biogeographic and phylogenetic reconstruction shown in Fig. 1. Table S5.-Evolutionary models and rates, and summary statistics including ESS values from the species level biogeographic and phylogenetic reconstructions used for the SPREAD plots. Figure S1.-All specimens, for which we had coordinates, plotted on a word map. Figure S2.-A tanglegram showing the level of concordance between the two phylogenetic markers (COI and EF1a). Figure S3.-Mismatch distribution plots showing the distribution of distances between alleles expected under stable population size and the empirical data. Figure S4.-EF1 a haplotype network. Figure S5.-Mantel tests of genetic and geographic distance. (PDF $2578 \mathrm{~kb}$ )

\section{Competing interest}

The authors declare that they have no competing interests.

\section{Authors' contributions}

The study was initially designed and conceived by LRK and BHJ, as a Master's thesis project for TS. JG participated in the design of the final version of the study, carried out the analyses, and drafted the final version of the manuscript. TS helped draft the manuscript in its early versions, carried out the molecular lab work and participated in the first data analyses. LRK collected field data and helped draft the final manuscript. BHJ collected field data, participated in the design of the final version of the study, and helped draft the final manuscript. All authors read and approved the final manuscript.

\section{Acknowledgments}

We thank Jiri Hulcr, Carlos Ruiz and Anthony Cognato for providing samples and the Research Council of Norway for funding (grant no.: 170565N40).

\section{Author details}

${ }^{1}$ Natural History Collections, University Museum of Bergen, University of Bergen, P.O. box 78005020 Bergen, Norway. Department of Biology, University of Bergen, P.O. box 78005020 Bergen, Norway.

Received: 11 December 2015 Accepted: 4 February 2016 Published online: 15 February 2016

\section{References}

1. Walker B, Steffen W. An overview of the implications of global change for natural and managed terrestrial ecosystems. Conserv Ecol. 1997;1 (2):2. 
2. Gurevitch J, Padilla DK. Are invasive species a major cause of extinctions? TREE. 2004;19(9):470-4.

3. McNeely JA. Human dimensions of invasive alien species. Washington: Island Press; 2005.

4. Cronk QCB, Fuller JL. Plant invaders: the threat to natural ecosystems. London: Chapman \& Hall; 1995.

5. Pimentel D, Zuniga R, Morrison D. Update on the environmental and economic costs associated with alien-invasive species in the united states. Ecol Econ. 2005;52(3):273-88

6. Williamson M, Fitter A. The varying success of invaders. Ecology. 1996;77(6): 1661-6.

7. Kolar CS, Lodge DM. Progress in invasion biology: predicting invaders. TREE. 2001;16(4):199-204.

8. Simberloff $D$. The role of propagule pressure in biological invasions. Annu Rev Ecol Evol Syst. 2009:40:81-102.

9. Simberloff D. Introduced insects: a biogeographic and systematic perspective. In: Mooney HA, Drake JA, editors. Ecology of ecological invasions of north america and hawaii. New York: Springer; 1986. p. 3-26.

10. Baker HG. Self-compatibility and establishment after 'long-distance' dispersal. Evolution. 1955;9:347-9.

11. Jordal BH, Beaver RA, Kirkendall LR. Breaking taboos in the tropics: inbreeding promotes colonization by wood-boring beetles. Global Ecol Biogeogr. 2001;10(4):345-58.

12. Allendorf FW, Lundquist LL. Introduction: population biology, evolution, and control of invasive species. Conserv Biol. 2003;17(1):24-30

13. Price SC, Jain SK. Are inbreeders better colonizers? Oecologia. 1981;49(2):283-6.

14. Terhivuo J, Saura A. Dispersal and clonal diversity of north-European parthenogenetic earthworms. Biol Invasions. 2006;8(6):1205-18.

15. Haack RA, Rabaglia RJ. Exotic bark and ambrosia beetles in the USA: potential and current invaders. In: Peña JE, editor. Potential invasive pests of agricultural crops. Wallingford: CAB International; 2013. p. 48-74.

16. Andersen HF, Jordal BH, Kambestad M, Kirkendall LR. Improbable but true: the invasive inbreeding ambrosia beetle xylosandrus morigerus has generalist genotypes. Ecol Evol. 2012;2(1):247-57.

17. Darwin C. The effects of cross and self fertilisation in the vegetable kingdom. London: John Murray; 1876.

18. Blackburn TM, Lockwood JL, Cassey P. The influence of numbers on invasion success. Mol Ecol. 2015;24(9):1942-53.

19. Bock DG, Caseys C, Cousens RD, Hahn MA, Heredia SM, Hübner S, Turner KG, Whitney KD, Rieseberg LH. What we still don't know about invasion genetics. Mol Ecol. 2015;24(9):2277-97.

20. Avilés L, Purcell J. The evolution of inbred social systems in spiders and other organisms: from short-term gains to long-term evolutionary dead ends. Adv Study Behav. 2012;44:99-133.

21. Crnokrak P, Barrett SCH. Perspective: purging the genetic load: a review of the experimental evidence. Evolution. 2002;56(12):2347-58.

22. Courchamp F, Clutton-Brock T, Grenfell B. Inverse density dependence and the allee effect. TREE. 1999;14:405-10.

23. Marini L, Haack RA, Rabaglia RJ, Toffolo EP, Battisti A, Faccoli M. Exploring associations between international trade and environmental factors with establishment patterns of exotic scolytinae. Biol Invasions. 2011;13(10):2275-88.

24. Beaver RA. Insect-fungus relationships in the bark and ambrosia beetles. In: Wilding N, Collins NM, Hammond PM, Webber JF, editors. Insect-fungus interactions. London: Academic; 1989. p. 121-43.

25. Hulcr J, Mogia M, Isua B, Novotny V. Host specificity of ambrosia and bark beetles (Col., curculionidae: scolytinae and platypodinae) in a New guinea rainforest. Ecol Entomol. 2007;32(6):762-72.

26. Haack RA. Exotic bark-and wood-boring coleoptera in the United States: recent establishments and interceptions. Can J For Res-Rev Can Rech For. 2006;36(2):269-88.

27. Sauvard D, Branco M, Lakatos F, Faccoli M, Kirkendall L. Weevils and bark beetles (coleoptera, curculionoidea). chapter 8.2. BioRisk. 2010;4:219-66.

28. Beeson CFC. The ecology and control of the forest insects of India and the neighbouring countries. 2nd ed. Government of India: New Delhi; 1961.

29. Browne FG. Some aspects of host selection among ambrosia beetles in the humid tropics of south-east Asia. Malayan Forestry. 1958;21:164-82.

30. Browne FG. The biology of malayan scolytidae and platypodidae. Malayan Forest Records. 1961;22:1-255.

31. Kalshoven LGE. Studies on the biology of indonesian scolytoidea. 4. Data on the habits of scolytidae. Tijdschr Entomol. 1958;101:157-80.
32. Schedl KE. Breeding habits of arboricole insects in central Africa. In: Xth international congress of entomology: august 17-25 1956. Montreal. 1956;1:183-97.

33. Bain J. Overseas wood-and bark-boring insects intercepted at New Zealand ports. Forest Research Institute, New Zealand Forest Service. 1977;63:28.

34. Haack RA. Intercepted scolytidae (coleoptera) at U.S. Ports of entry: 19852000. Integr Pest Manage Rev. 2001;6:253-82.

35. Brockerhoff EG, Bain J, Kimberly M, Knizek M. Interception frequency of exotic bark and ambrosia beetles (coleoptera: scolytinae) and relationship with establishment in New Zealand and worldwide. Can J For Res-Rev Can Rech For. 2006;36:289-98.

36. Brockerhoff EG, Jones DC, Kimberley MO, Suckling DM, Donaldson T. Nationwide survey for invasive wood-boring and bark beetles (coleoptera) using traps baited with pheromones and kairomones. For Ecol Manage. 2006;228(1-3):234-40.

37. Kirkendall L, Faccoli M. Bark beetles and pinhole borers (curculionidae, scolytinae, platypodinae) alien to Europe. ZooKeys. 2010;56:227-51.

38. Haack RA, Petrice TR. Bark-and wood-borer colonization of logs and lumber after heat treatment to ISPM 15 specifications: the role of residual bark. J Econ Entomol. 2009;102(3):1075-84.

39. Brockerhoff EG, Kimberley M, Liebhold AM, Haack RA, Cavey JF. Predicting how altering propagule pressure changes establishment rates of biological invaders across species pools. Ecology. 2014;95(3):594-601.

40. Schedl KE. New bark beetles and ambrosia beetles. Stylops. 1935;4(12):273.

41. Schreiner J. Neue tomicinen von der goldkuste Afrikas. Deutsche Entomologische Zeitschrift. 1882;26:246-8.

42. Blandford WFH. Family scolytidae. Biologia Centrali-Americana, Coleoptera. 1897;4(6):145-84.

43. Wood SL. Bark and ambrosia beetles of south America (coleoptera, scolytidae). Provo, Utah: Brigham Young University; 2007.

44. Wood SL. The bark and ambrosia beetles of north and central America (coleoptera: scolytidae), a taxonomic monograph. Gt Basin Nat Mem. 1982;6: $1-1359$.

45. Hulcr J, Cognato Al. Xyleborini of New Guinea, a taxonomic monograph (coleoptera: curculionidae: scolytinae). Lanham, Maryland: Thomas Say Publications in Entomology, Entomological Society of America; 2013.

46. Jordal $\mathrm{BH}$. Elongation factor 1a resolves the monophyly of the haplodiploid ambrosia beetles xyleborini (coleoptera: curculionidae). Insect Mol Biol. 2002;11:453-65.

47. Campbell V, Legendre P, Lapointe F-J. The performance of the congruence among distance matrices (CADM) test in phylogenetic analysis. BMC Evol Biol. 2011;11(1):64.

48. Normark BB, Jordal BH, Farrell BD. Origin of a haplodiploid beetle lineage. Proc R Soc B. 1999:266:2253-9.

49. Thompson JD, Higgins DG, Gibson TJ. Clustal-W_-improving the sensitivity of progressive multiple sequence alignment through sequence weighting, position-specific Gap penalties and weight matrix choice. Nucleic Acids Res. 1994:22(22):4673-80

50. Hall TA. BioEdit: a user-friendly biological sequence alignment editor and analysis program for windows 95/98/NT. Nucleic Acids Symp Ser. 1999:41:95-8.

51. Paradis E. Pegas: an R package for population genetics with an integratedmodular approach. Bioinformatics. 2010;26(3):419-20.

52. Lemey P, Rambaut A, Drummond AJ, Suchard MA. Bayesian phylogeography finds its roots. PLoS Comput Biol. 2009;5(9), e1000520.

53. Ferreira MAR, Suchard MA. Bayesian analysis of elapsed times in continuoustime markov chains. Canadian Journal of Statistics-Revue Canadienne De Statistique. 2008;36(3):355-68.

54. Bielejec F, Rambaut A, Suchard MA, Lemey P. SPREAD: spatial phylogenetic reconstruction of evolutionary dynamics. Bioinformatics. 2011;27(20):2910-2.

55. Wang Q, Liu J, Allen GA, Ma Y, Yue W, Marr KL, Abbott RJ. Arctic plant origins and early formation of circumarctic distributions: a case study of the mountain sorrel. Oxyria digyna New Phytol. 2016;209(1):343-53.

56. Guarnizo CE, Werneck FP, Giugliano LG, Santos MG, Fenker J, Sousa L, D'Angiolella AB, dos Santos AR, Strüssmann C, Rodrigues MT et al. Cryptic lineages and diversification of an endemic anole lizard (squamata, dactyloidae) of the cerrado hotspot. Mol Phylogenet Evol. 2016;94(Part A): 279-89.

57. Darriba D, Taboada GL, Doallo R, Posada D. JModelTest 2: more models, new heuristics and parallel computing. Nat Methods. 2012;9(8):772-2.

58. Guindon S, Gascuel O. A simple, fast, and accurate algorithm to estimate large phylogenies by maximum likelihood. Syst Biol. 2003;52(5):696-704. 
59. Drummond AJ, Suchard MA, Xie D, Rambaut A. Bayesian phylogenetics with BEAUti and the BEAST 1.7. Mol Biol Evol. 2012;29(8):1969-73.

60. Rambaut A, Suchard MA, Xie D, Drummond AJ. Tracer v1.6, Available from http://beast.bio.ed.ac.uk/Tracer. 2014.

61. Excoffier L, Laval G, Schneider S. Arlequin (version 3.0): an integrated software package for population genetics data analysis. Evol Bioinforma. 2005; $1: 47-50$

62. Librado P, Rozas J. DnaSP v5: a software for comprehensive analysis of DNA polymorphism data. Bioinformatics. 2009;25(11):1451-2.

63. Dray S, Dufour A-B. The ade4 package: implementing the duality diagram for ecologists. J Stat Softw. 2007;22(4):1-20.

64. R Development Core Team. R: a language and environment for statistical computing. In. Vienna, Austria, http://www.R-project.org; 2014.

65. Evans TA, Forschler BT, Grace JK. Biology of invasive termites: a worldwide review. Annu Rev Entomol. 2013;58(1):455-74.

66. Suarez AV, Holway DA, Case TJ. Patterns of spread in biological invasions dominated by long-distance jump dispersal: insights from argentine ants. Proc Natl Acad Sci. 2001;98(3):1095-100

67. Foucaud J, Orivel J, Loiseau A, Delabie JH, Jourdan H, Konghouleux D, Vonshak M, Tindo M, Mercier JL, Fresneau D. Worldwide invasion by the little fire ant: routes of introduction and eco-evolutionary pathways. Evol Appl. 2010;3(4):363-74.

68. Gauthier N. Multiple cryptic genetic units in hypothenemus hampei (coleoptera: scolytinae): evidence from microsatellite and mitochondrial DNA sequence data. Biol J Linn Soc. 2010;101(1):113-29.

69. Jordal BH. Molecular phylogeny and biogeography of the weevil subfamily platypodinae reveals evolutionarily conserved range patterns. Mol Phylogenet Evol. 2015;92:294-307.

70. Kirkendall LR, Biedermann PHW, Jordal BH. Evolution and diversity of bark and ambrosia beetles. In: Vega FE, Hofstetter RW, editors. Bark beetles: biology and ecology of native and invasive species. Waltham, Massachusetts: Academic; 2014.

71. Kirkendall $L R$, Jordal BH. The bark and ambrosia beetles (curculionidae, scolytinae) of cocos island, costa rica and the role of mating systems in island zoogeography. Biol J Linn Soc. 2006;89(4):729-43.

72. Cognato Al, Hulcr J, Dole SA, Jordal BH. Phylogeny of haplo-diploid, fungusgrowing ambrosia beetles (coleoptera: curculionidae: scolytinae: xyleborini) inferred from molecular and morphological data. Zool Scr. 2011;40(2):174-86.

73. Kirkendall LR. Ecology and evolution of biased sex ratios in bark and ambrosia beetles (scolytidae). In: Wrensch DL, Ebbert MA, editors. Evolution and diversity of sex ratio: Insects and mites. New York: Chapman and Hall; 1993. p. 235-345.

74. Rabaglia RJ. The validity of xyleborus impressus eichhoff (coleoptera : curculionidae : scolytinae) as distinct from xyleborus ferrugineus (fabricius). Coleopt Bull. 2005;59(2):261-6.

75. Wood SL, Bright D. A catalog of scolytidae and platypodidae (coleoptera). part 2: taxonomic index. Gt Basin Nat Mem. 1992;13:1-1553.

\section{Submit your next manuscript to BioMed Central and we will help you at every step:}

- We accept pre-submission inquiries

- Our selector tool helps you to find the most relevant journal

- We provide round the clock customer support

- Convenient online submission

- Thorough peer review

- Inclusion in PubMed and all major indexing services

- Maximum visibility for your research

Submit your manuscript at www.biomedcentral.com/submit 